\title{
Histological and Immunohistochemical Study of the Effect of Alendronate on the Submandibular Salivary Gland of Adult Male Albino Rat and the Possible Protective Effect of Propolis
}

\author{
AYA A. ABO EL-YAZED, M.Sc.; SAMAH K. EL-SAYED, M.D.; REDA H. EL-BAKARY, M.D. and \\ NAFISA A. EL-BAKARY, M.D. \\ The Department of Histology, Faculty of Medicine, Tanta University, Tanta, Egypt
}

\begin{abstract}
Background: Alendronate is an anti-bone-resorptive drug used in the treatment of post-menopausal osteoporosis. Its long administration induced organ damage especially the submandibular salivary glands. Propolis is a natural resinous substance with an antioxidant and anti-inflammatory actions

Aim of Study: This work was performed to study the effect of alendronate on the histological structure of the submandibular salivary gland of adult male albino rat and the possible protective effect of propolis.

Material and Methods: 40 adult male albino rats were divided into 4 groups (10 rats each); control group, Group A: Rats received $100 \mathrm{mg} / \mathrm{kg}$ body weight propolis, Group B: Rats received $2.5 \mathrm{mg} / \mathrm{kg}$ body weight alendronate and Group $\mathrm{C}$ : Rats received propolis 30 minutes before alendronate. Doses were given orally for consecutive 30 days then gland specimens were taken for histological and immunohistochemical studies using light and electron microscopes.
\end{abstract}

Results: H \& E and toluidine blue results of Group B revealed disturbed architecture, separated lobules and acini, cytoplasmic vacuolations, dark nuclei, irregular ducts and congested blood vessels. PAS-AB showed significant increase in its mean color intensity as compared with control group while a-SMA glandular myoepithelial cells immunostaining expressed significant decrease in its mean color intensity in comparison to control group. Electron microscopic examination of acinar and duct cells revealed cytoplasmic vacuolations, rarefaction, abnormal shaped mitochondria with lost cristae, electron dense bodies, dilated RER and Golgi apparatus, apparently increased secretory granules with coalescence, compressed shrunken hyperchromatic nuclei, nuclear membrane irregularities, and dilated perinuclear and intercellular spaces. Group C showed moderate improvement of the previous pathological findings.

Conclusion: Alendronate induced damaging effects on the histological structure of submandibular salivary gland in

Correspondence to: Dr. Aya A. Abo El-Yazed, The Department of Histology, Faculty of Medicine, Tanta University, Tanta, Egypt rats and the administration of propolis could moderately improve such damage through its anti-oxidant and antiinflammatory effects.

Key Words: Propolis - Alendronate - Submandibular Salivary Gland - Histopathology-Electron microscopy.

\section{Introduction}

PROPOLIS is a natural resinous substance collected by honeybees from buds and exudates of different plants [1]. Its chemical composition is variable depends on the plant sources [2]. Propolis composed of polyphenols as flavonoids that, accompanied by phenolic acid, aldehydes, phenolic aldehydes, and ketones. Besides, volatile oils, aromatic acids as well as waxes. It also contains a number of essential elements like magnesium, calcium, iron, nickel, zinc and vitamins [3].

Propolis has many beneficial effects as antiinflammatory, immunomodulatory, antioxidant, antimicrobial, as well as antitumor effects. These effects make it widely used in the treatment of various conditions such as microbial infections, wounds, burns, sore throat, ulcers as well as diabetes $[4,5]$. It is also considered as a rich source of natural antioxidants and can be used as a protective agent against various free radical' associated degenerative diseases $[6,7]$.

Alendronate is one of the nitrogen containing bisphosphonates (BPs) which are synthetic analogues of pyrophosphate and are used in the treatment of disorders that involve excessive bone resorption such as osteoporosis, Paget's disease, and hypercalcemia of malignancy [8]. Alendronate mediates its antiresorptive action mainly through inhibiting the action of osteoclasts [9]. 
Its long term administration could produce a wide variety of adverse effects as nausea, vomiting, epigastric pain and dyspepsia due to irritation of the mucosa of the gastrointestinal tract. Also, atrial fibrillation and deterioration in renal function may occur, especially in patients with renal insufficiency $[10,11]$. One of the important side effects is decreasing salivary secretion, so the patient suffers from dry and burning mouth [12]

Salivary secretion is essential for lubrication and coating of the oral cavity. It helps for speech, mastication and swallowing in addition to its antibacterial and antiviral effects. Furthermore, it has an important role in dissolving food particles by stimulating taste receptors. Moreover, saliva initiates digestion of complex carbohydrate by salivary amylase enzyme and triglycerides by lingual lipase $[13,14]$. Moreover, saliva has an important effect on tooth as it prevents their demineralization by buffering bacterial acids produced during sugar metabolism [15]

From these previous data, we can predict that dry mouth is a big health problem. So this work aims to evaluate the possible protective effect of propolis on alendronate-induced changes on the submandibular salivary glands in adult male albino rats by means of histological as well as electron microscopic studies.

\section{Material and Methods}

This work was carried out from January 2017 till August 2017 at Histology Department, Faculty of Medicine, Tanta University and at the Electron Microscopic Unit, Faculty of Agriculture, Mansoura University.

\section{Experimental animals:}

This work carried out using 40 adult male albino rats weighing 120-180 grams. The animals housed in suitable clean properly ventilated cages under similar environmental conditions and fed on a similar commercial laboratory diet and water. The experiments directed following the guidelines on the care and usage of experimental animals of Tanta University, Faculty of Medicine with the authorization of The Animal Experiment Committee of the faculty. Moreover, the bodies of the sacrificed animals were packed in a special package according to the safety precaution and infection control measures then sent with the hospital biohazards.

\section{The experimental groups:}

Animals randomly divided into four groups (10 rats each); control group: Subdivided into further two subgroups: Subgroup C 1: Rats kept without treatment and subgroup $\mathrm{C} 2$ : Rats given $1 \mathrm{ml}$ distilled water; Group A: Rats given propolis (Sigma, Cairo, Egypt) in a dose of $100 \mathrm{mg} / \mathrm{kg} /$ day [16,17] ; Group B: Rats given alendronate (Merck \& Co., Inc., white house station, N.J., USA) in a dose of 2.5 $\mathrm{mg} / \mathrm{kg} /$ day 30 minutes before breakfast according to [18] and Group C: Rats given $100 \mathrm{mg} / \mathrm{kg} / \mathrm{day}$ propolis before $2.5 \mathrm{mg} / \mathrm{kg} /$ day alendronate.

Rats received their doses orally through intragastric tube, for 30 consecutive days. On the day after the last dose, animals anesthetized by ether inhalation. Then, the submandibular salivary glands carefully dissected and removed, then, processed for histological, immunohistochemical and electron microscopic examination.

\section{Preparation of specimens for paraffin sections:}

Gland specimens fixed in $10 \%$ formalin buffered saline for 48 hours. Then dehydrated, cleared, and infiltrated with molten paraffin wax, followed by embedding in hard paraffin. Finally, sections of 3-5 microns obtained and prepared for histological and immunohistochemical examination [19].

\section{1- Haematoxylin and Eosin $(H \& E)$ stain: Sec-} tions dewaxed, then rehydrated. After that, sections placed in Ehrlich's hematoxylin for 30 minutes, then at $1 \%$ eosin $\mathrm{Y}$ for 10 minutes. Lastly, sections were dehydrated, cleared, and mounted.

\section{2- Combined (Periodic Acid Schiff-Alcian Blue)} $(P A S-A B)$ stain: Sections dewaxed in xylene, then rehydrated and stained with alcian blue solution for 30 minutes, followed by oxidation with periodic acid. Then, sections covered with Schiff's reagent for 15 minutes and finally, sections dehydrated, cleared, and mounted with Canada balsam.

\section{3- Immunohistochemical staining for alpha-smooth} muscle actin $(\alpha-S M A)$ : Sections deparafinated, and hydrated. Then, sections placed in $3 \%$ hydrogen peroxide in methanol for 30 minutes at room temperature to inhibit the formation of background staining from the endogenous peroxidase activity. After that, slides rinsed in phosphate buffered saline, then sections incubated with citric acid ( $\mathrm{pH}$ 6.0) in a microwave oven at $121^{\circ} \mathrm{C}$ for 5 minutes for antigen retrieval and allowed to cool for 8 minutes at room temperature. Next, the sections incubated with normal goat serum to prevent non-specific protein binding followed by the addition of a-SMA 
primary antibody (1:50) (Abcam, USA) overnight at $4^{\circ} \mathrm{C}$. Slides then, incubated with biotinylated peroxidase-conjugated secondary antibody for 1 hour and rinsed in PBS buffer. Afterwards, Diaminobenzidine (DAB) solution applied to the sections for 5-10 minutes, followed by washing in PBS, then counterstaining with Mayer's haematoxylin for 1-2 minutes. Finally, sections dehydrated, cleared, mounted in Canada balsam, and examined by a light microscope (Olympus, Japan) [20,21] . For negative controls, the same procedure performed by replacing the step of addition of primary antibody by PBS. While, the positive control is the normal human colon mucosal smooth muscle tissue (abcam124964).

\section{Prepr
study:}

Preparation of sections for electron microscopic

The submandibular salivary gland specimens a cut by sharp razor blade into small pieces of $1 \mathrm{~mm}^{3}$ and prepared for semithin and ultrathin sections according to [22] . Briefly, specimens immersed in $4 \%$ glutaraldehyde in phosphate buffer with $\mathrm{pH} 7.2$ at $4^{\circ} \mathrm{C}$ for 2 hours. Followed by, postfixation in $1 \%$ osmium tetroxide. Then, sections dehydrated, infiltrated in epoxy resins, embedded in resin and polymerized in an oven at $60-70^{\circ} \mathrm{C}$ for 1-2 days. After that, ultrathin sections 40$150 \mathrm{~nm}$ obtained using LKB ultramicrotome then, picked up on 200 mesh, copper grids and double stained, with uranyl acetate and lead citrate. Lastly, the specimens examined and photographed using (JEOL-JEM-100 SX electron microscope, Japan) at the Electron Microscopy Unit, Faculty of Medicine, Tanta University and at the Electron Microscopic Unit, Faculty of Agriculture, Mansoura University.

\section{Statistical analysis:}

A- Estimation of glandular PAS -AB color intensity: 10 different PAS-AB stained images (X400)/ each group used by the image $\mathrm{J}$ software $(\mathrm{Na}-$ tional Institute of Health, Bethesda, Maryland, USA), to estimate PAS-AB color intensity of the submandibular salivary glandular' tissue in the different experimental groups.

\section{B- Evaluation of a-SMA immunostaining color} intensity in the myoepithelial cells of the submandibular salivary gland: By image $\mathbf{J}$ software (National Institute of Health, Bethesda, Maryland, USA), a-SMA immunostaining color intensity in the myoepithelial cells of the submandibular salivary gland evaluated. Through which, 10 different images (X400) of each group, containing no blood vessels used.

The statistical significant differences between the experimental groups valued using Minitab Statistical Software for Windows (Version 16.1, Minitab Inc., State College, PA, USA). Then, the variances of data analyzed using either two-tailed Student's $t$-test or the Mann-Whitney's U-test after evaluation by F-test. Through which, $p$-value $<0.05$ considered to be significant.

\section{Results}

\section{Histological results:}

In the present work, histological and immunohistochemical results of Group A (propolis) are similar to the control group.

\section{A- Light microscopic study:}

I- Haematoxylin and eosin stained sections: Through examination of the control group sections, the normal histological structure of the submandibular salivary gland found. By which, it was divided into numerous lobules by connective tissue septa conveying blood vessels and large excretory ducts lined by stratified columnar epithelium. The serous acini appeared spherical in shape, lined by pyramidal cells with a moderate basophilic cytoplasm, and rounded basally situated nuclei. While, the Intercalated Ducts (IDs), seen lined by short cuboidal cells with centrally located rounded nuclei. Also, flattened myoepithelial cells seen partially surrounding the serous acini and IDs. Moreover, the Granular Convoluted Tubules (GCTs) lined by tall columnar cells with eosinophilic cytoplasm and large rounded basally situated nuclei, and the Striated Ducts (SDs) lined by columnar cells with centrally located rounded nuclei and intensely eosinophilic cytoplasm with basal striations Fig. (1A-D).

Conversely, Group B (alendronate group), revealed marked disturbed gland architecture with disorganized widely separated acini, in addition to irregular excretory ducts with narrow lumen and disorganized darkly stained nuclei besides congested blood vessels. Moreover, the acinar cells showed numerous cytoplasmic vacuolations in addition to darkly stained nuclei. While, the GCTs, appeared surrounded with wide space besides, vacuolated, fragmented cytoplasm, disarranged darkly stained nuclei Fig. (2A-D).

As regards Group C (alendronate and propolis group), it showed a moderate improvement when 
compared to the control group. Through which, some serous acinar and GCT cells showed cytoplasmic vacuolation besides, few SD cells with flattened nuclei Fig. (2E,F).

II- Combined Periodic Acid Schiff-Alcian Blue (PAS-AB) results: Combined PAS-AB stained sections of the control group showed, serous acini with mild PAS-positive reaction and moderately positive alcian blue staining, while, the GCTs showed moderate PAS-positive reaction. Considering IDs and SDs, they showed faint PAS positive staining. Conversely, the alendronate group showed, serous acinar cells with moderate PAS positive reaction and strong alcian blue reaction while, the GCT cells showed an intense PAS positive reaction. The ID and SD cells showed moderate PAS positive reaction as well as accumulation of $A B$ positive material in the duct lumen. As regards the propolis $\&$ alendronate group, they displayed few SDs with accumulated $\mathrm{AB}$ positive material in their lumen and some GCT cells with an intense PAS positive reaction Fig. (3A-D).

Considering the statistical results of the mean color intensity of PAS-alcian blue, it showed significant increase in the alendronate group as compared with the control group; in contrast to a significant decrease in the alendronate and propolis group in comparison to alendronate group Fig. (4).

III- Immunohistochemical results for a-SMA: Immunostained $a$-SMA sections from the rat submandibular salivary gland of the control group showed, strong positive reaction in the cytoplasm of the myoepithelial cells at the periphery of the serous acini as well as the IDs. While in the GCTs and SDs, there was no observed reaction at their periphery. Furthermore, the smooth muscle cells lining the wall of the blood vessels showed positive immunoreaction. On the contrary, the alendronate group expressed weak positive reaction at the periphery of both serous acini and IDs. Whereas, the GCTs and SDs showed negative reaction. However, propolis \& alendronate group exhibited some acini with weak positive immunoreaction Fig. (5AD).

As regards, the mean color intensity of $a$-SMA immunostaining of the myoepithelial cells in the submandibular salivary glandular tissue; it revealed significant decrease in the alendronate group as compared with the control group. Besides, significant increase in the propolis $\&$ alendronate group in comparison to alendronate group Fig. (6).

\section{B- Electron microscopy study:}

1-Acinar cells: EM examination of the control group revealed, pyramidal shaped serous acinar cells with basal rounded nuclei (some cells binucleated) and prominent nucleoli in addition to parallel arrays of RER, mitochondria, supranuclear Golgi complex, apical junctional complexes besides, secretory granules with different sizes and microgranular appearance. Moreover, the cells showed normally appeared intercellular space with flattened myoepithelial cells partially surrounding the acini. Alternatively, the alendronate group presented apparently increased granules with basal migration and coalescence of most of them. Along with, dilated Golgi apparatus, and RER, abnormal shaped mitochondria with lost cristae, and electron dense bodies. These all besides, nuclear membrane irregularity, shrunken electron dense nucleus and, dilated intercellular space. Furthermore, propolis $\&$ alendronate group revealed, few acinar cells with coalescence of some secretory granules and irregular cellular outlines Fig. (7A-D).

2-IDs: The control ID presented with two types of cells; granular and non-granular. Through which, their cytoplasm revealed, rounded centrally located nuclei in addition to junctional complexes and apical microvilli. Regarding the alendronate group, there was wide intercellular space, cytoplasmic vacuolations and shrunken electron dense nuclei. While, propolis \& alendronate group revealed, some irregular, destroyed ID cells that separated from its basement membrane Fig. (8A-C).

3- GCTs: GCTs of the control group, exposed tall columnar cells with electron dense granules occupying their apical two thirds while, the basal part was occupied by RER and mitochondria surrounding a rounded euchromatic nucleus with prominent nucleolus. On the contrary, GCTs of the alendronate group showed, apparently increased secretory granules, cytoplasmic vacuolation, together with cytoplasmic rarefaction, and nuclear membrane irregularities. Through EM examination of the propolis \& alendronate group, the GCTs, showed few cells with cytoplasmic rarefaction Fig. $(8 \mathrm{~A}-\mathrm{C})$.

4- SDs: EM examination of control SDs showed tall columnar cells with junctional complexes, and apical microvilli, small clear secretory vesicles located apically and large rounded centrally located euchromatic nuclei. Furthermore, the basal part of these cells showed deep infoldings of the plasma membrane that were parallel to the long axis of 
the cell with numerous rod shape mitochondria (palisade arrangement). As regards the SD cells of alendronate group, they displayed cytoplasmic vacuolations and rarefaction, and abnormal distribution of mitochondria around the nucleus, and mitochondria with lost cristae. These were associ- ated with electron dense bodies of variable sizes and irregular nuclear outlines. Even though, the SDs of propolis \& alendronate group revealed some changes such as, mitochondrial disarrangement and detachment of some SD cells from the basement membrane Fig. (10A-D).
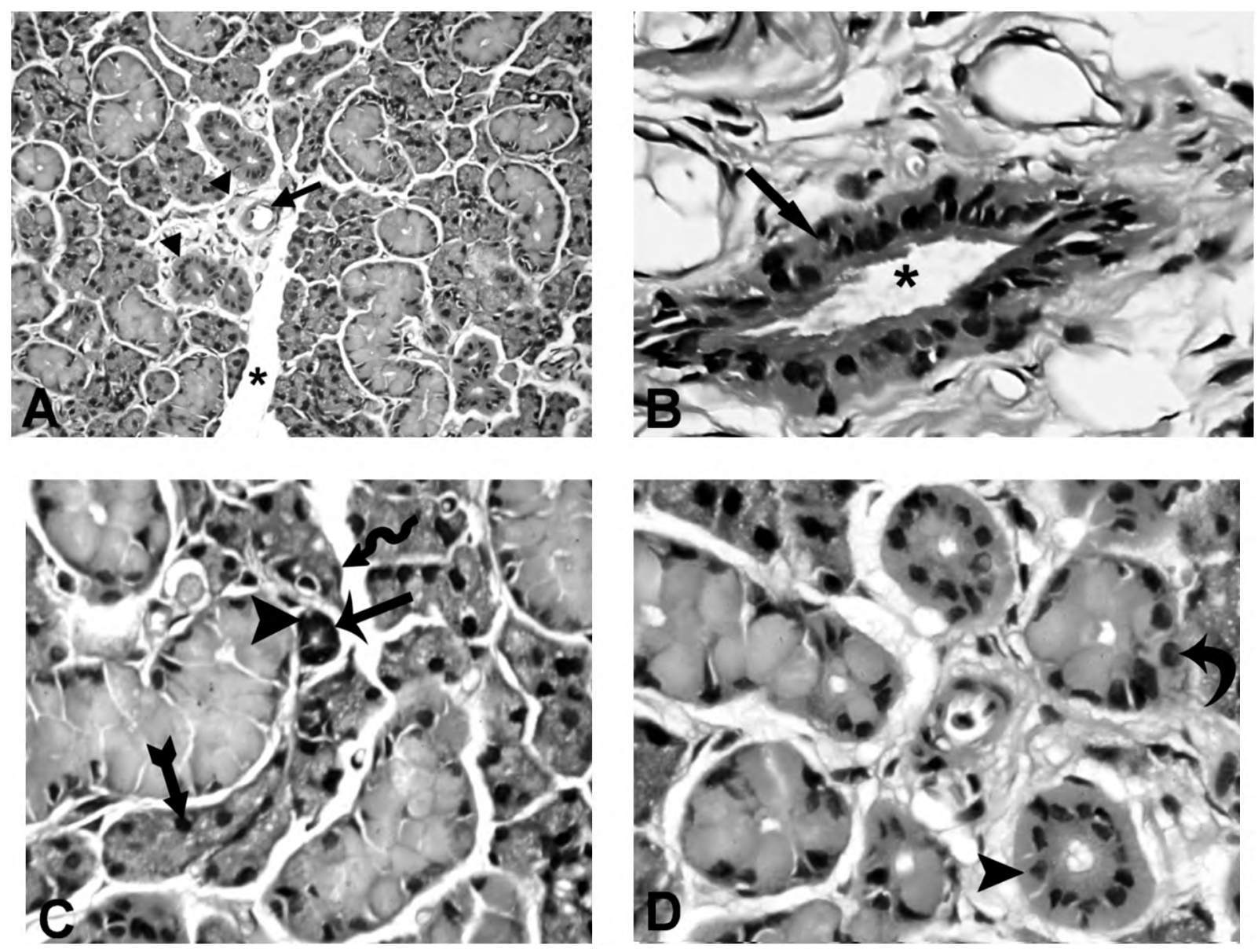

Fig. (1): Effect of propolis on H. \& E. stained sections of alendronate-induced changes in the submandibular salivary gland of rats' control group. A) Numerous lobules divided by connective tissue septa (*) conveying blood vessels $(\rightarrow)$ and excretory ducts (4) (H. \& E. X400). B) A large excretory duct with wide lumen (*) and lined with stratified columnar epithelium $(\rightarrow)$. (H \& E X1000). C) ID with low cuboidal cells having central rounded nuclei (thin arrow) and myoepithelial cells partially surrounding the ducts (4), serous acinar cells with basophilic cytoplasm, rounded basally situated nuclei (bifid arrow) and myoepithelial cells partially surrounding it (wavy arrow) (H. \& E. X1000), D) GCTs lined by tall columnar cells with eosinophilic cytoplasm and basally situated nuclei (curved arrow), SDs lined by tall columnar cells with rounded nuclei located near to cell apex (4 ). (H. \& E. X1000). 

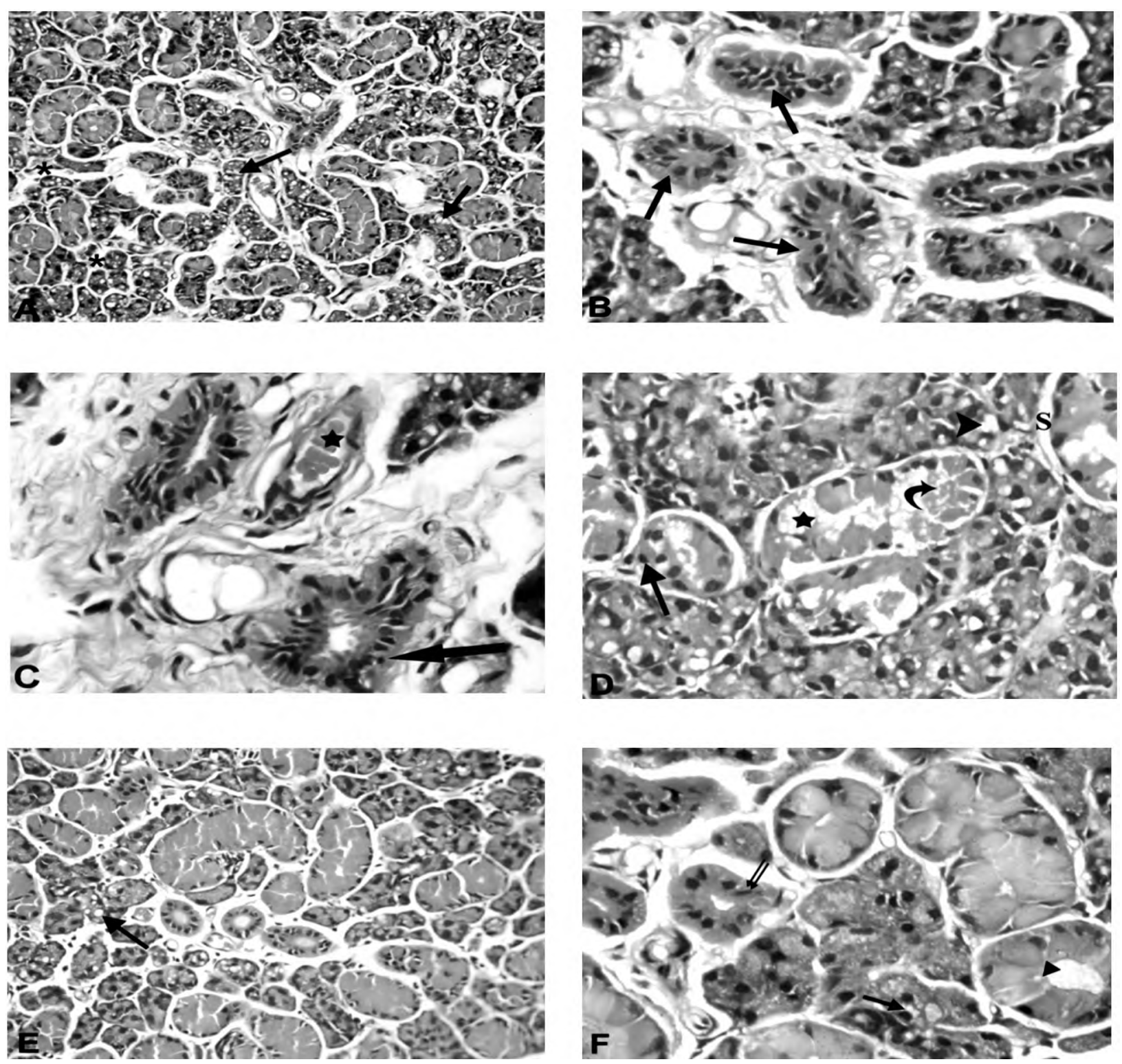

Fig. (2): Effect of propolis on H. \& E. stained sections of alendronate-induced changes in the submandibular salivary gland of rats' Group B (alendronate) \& Group C (Propolis \& alendronate). A) Alendronate group, showing marked disturbed gland architecture with disorganized widely separated acini $\left(^{*}\right)$ and acinar cell cytoplasmic vacuolations $(\rightarrow)(\mathrm{H}$. \& E. X 400). B) Alendronate group showing, irregular excretory ducts with narrow and obliterated lumen (wavy arrow). (H. \& E. X1000) C) Alendronate group, showing large excretory duct with disorganized darkly stained nuclei $(\rightarrow)$, and congested blood vessels (*). (H. \& E. X1000). D) Alendronate group, showing serous acini with cytoplasmic vacuolations (4), GCTs with vacuolated (*), and fragmented cytoplasm (curved arrow), darkly stained nuclei $(\rightarrow)$, and wide space around the tubules (S). (H. \& E. X1000). E) Propolis \& alendronate group, showing few serous acini with cytoplasmic vacuoles $(\rightarrow)$ (H. \& E. X400). F) Propolis \& alendronate group, showing few GCT cells with cytoplasmic vacuolation (4) and few SD cells with flattened nuclei (double arrow). (H. \& E. X1000). 

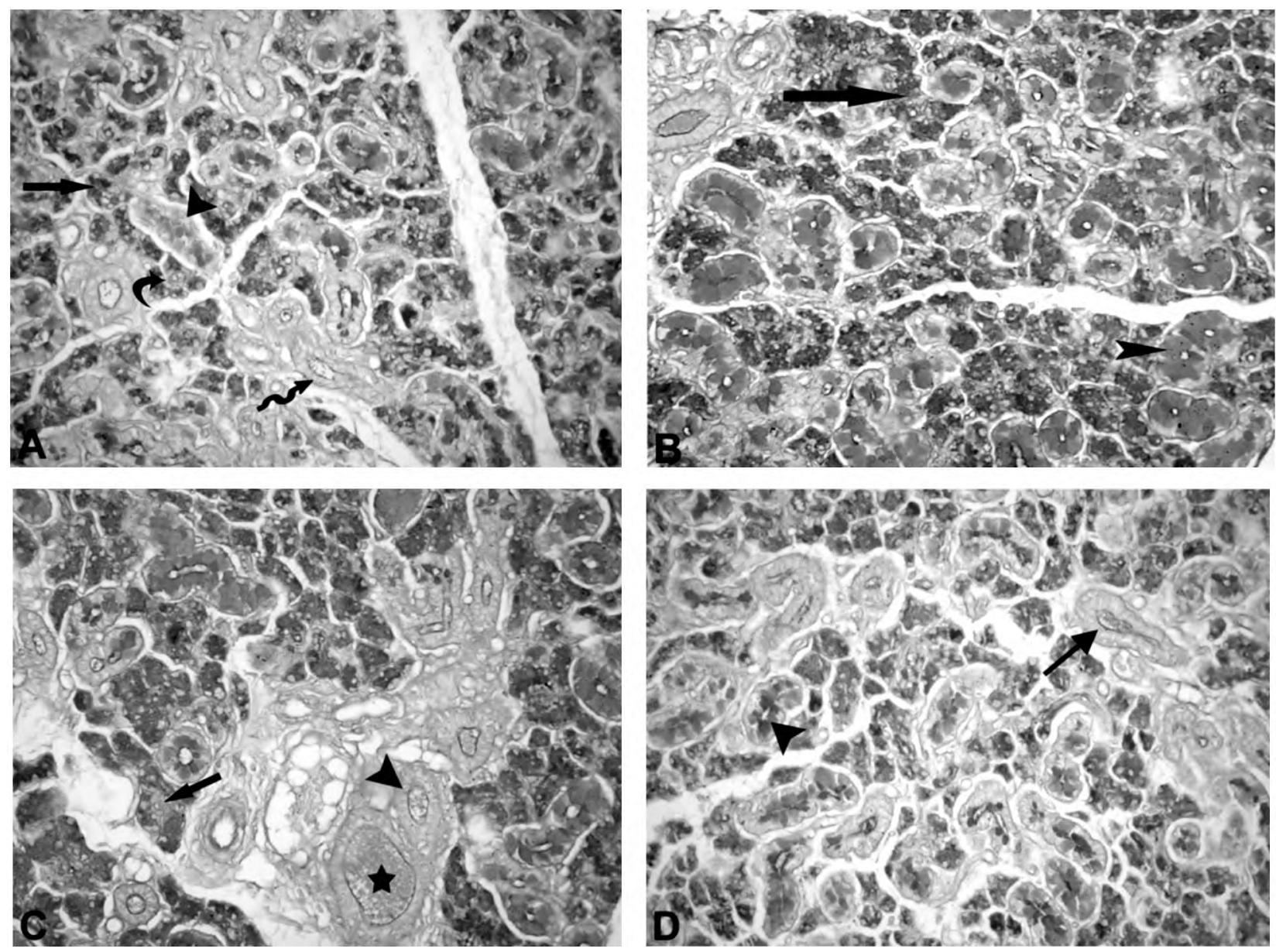

Fig. (3): Effect of propolis on PAS-AB stained sections of alendronate-induced changes in the submandibular salivary gland of the rats' experimental groups. A) control group showing, mild PAS positive, moderate positive alcian blue staining of serous acini $(\rightarrow)$, moderate PAS positive reaction of the GCT cells (4) and faint PAS positive staining of the ID (curved arrow) and SD cells (wavy arrow). B) Alendronate group showing, moderate PAS positive and strong positive alcian blue staining of serous acini $(\rightarrow)$, and intense PAS positive reaction of the GCT cells (4). C) Alendronate group showing, ID $(\rightarrow)$ and SD $(4)$ cells with moderate PAS positive reaction with accumulation of AB positive material in the duct lumen $(*)$. D) Propolis \& alendronate group showing, few SDs with accumulated secretory material in their lumen $(\rightarrow)$ and some GCT cells with intense PAS positive reaction (4 ). (PAS-AB X400).

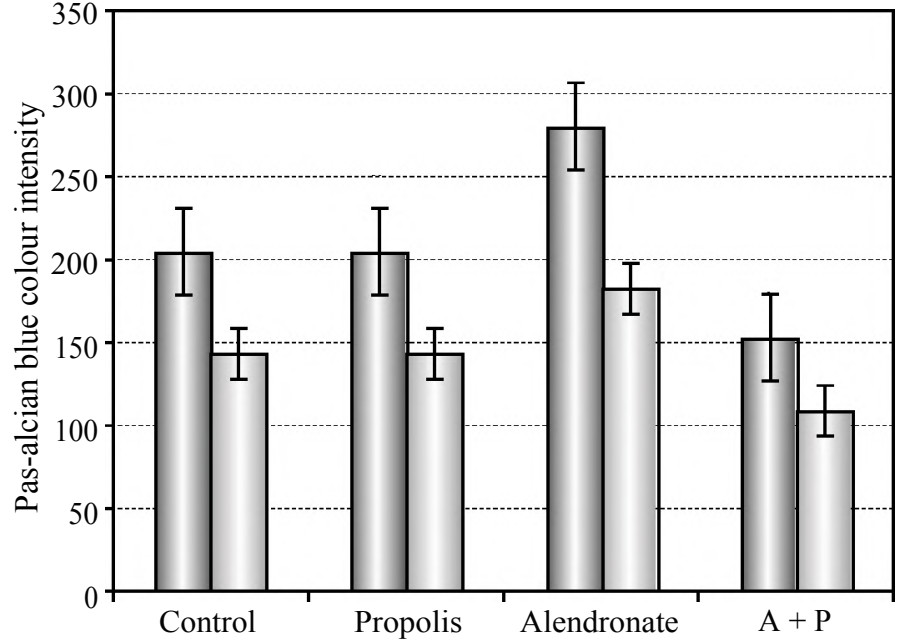

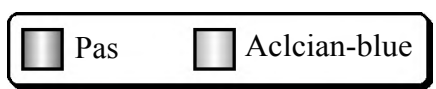

Fig. (4): The color intensity of PAS-AB of the submandibular glandular tissue of the different experimental groups expressed as mean \pm SEM.

\# : $p>0.05$ non-significant relative to control.

$*: p<0.05$ significant relative to control.

(a) : $p<0.05$ significant relative to alendronate group. 

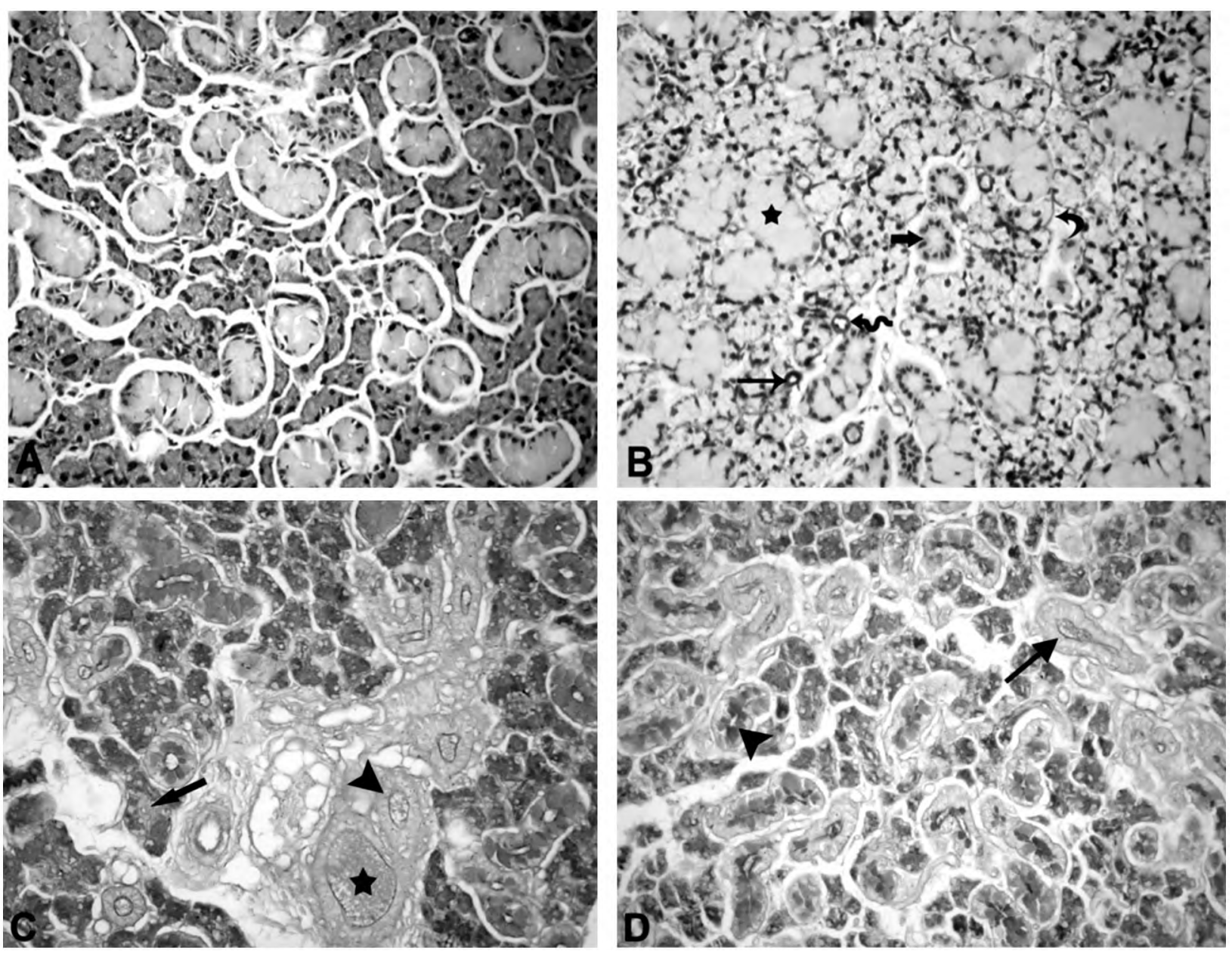

Fig. (5): Effect of propolis on alendronate- induced $\alpha$-SMA expression changes of the glandular myoepithelial cells of the rats experimental groups. A) Negative control of $\alpha$-SMA immunostained sections from rat submandibular salivary gland showing no reaction. B) Control group showing, strong positive $\alpha$-SMA immunoreaction at the periphery of the serous acini (curved arrow), ID (thin arrow), and the wall of the blood vessels (wavy arrow), negative immunoreaction at the periphery of GCTs $(*)$ and SDs (thick arrow). C) Alendronate group showing, serous acini (thick arrow), and ID (thin arrow) with $\alpha$-SMA weak positive immunoreaction at their periphery, GCTs (wavy arrow), and SDs (curved arrow) with negative reaction. (D) Propolis $\&$ alendronate group showing, some acini with $\alpha$-SMA weak positive immunoreaction $(\rightarrow)$. ( $\alpha$-SMA immunostaining X400).

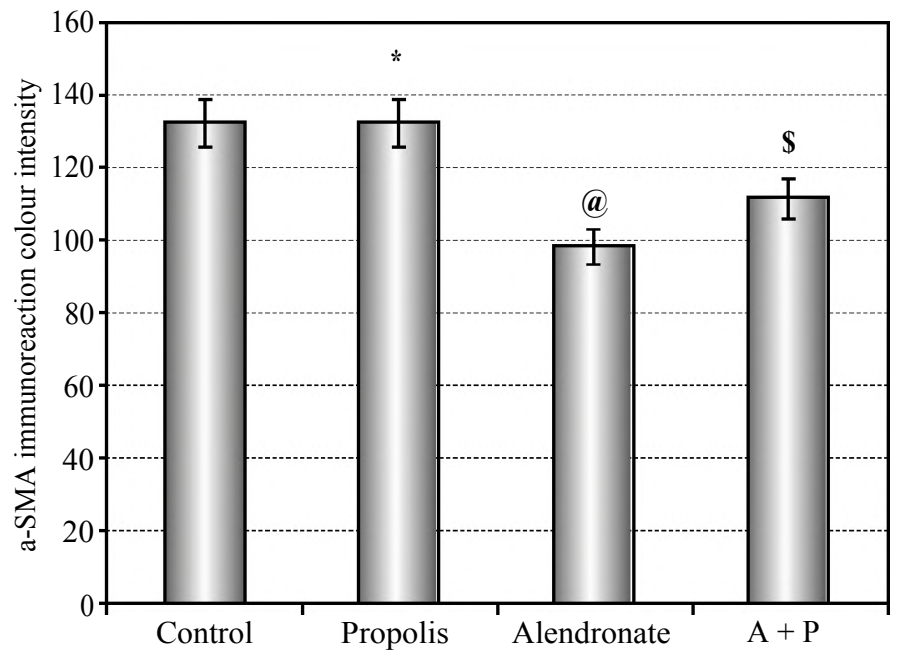

Fig. (6): The color intensity of $\alpha$-SMA immunostaining of the myoepithelial cells of the submandibular salivary glandular tissue of the different experimental groups expressed as mean \pm SEM.

* : $p>0.05$ non-significant relative to control.

(a) : $p<0.05$ significant relative to control.

$\$: p<0.05$ significant relative to alendronate group. 

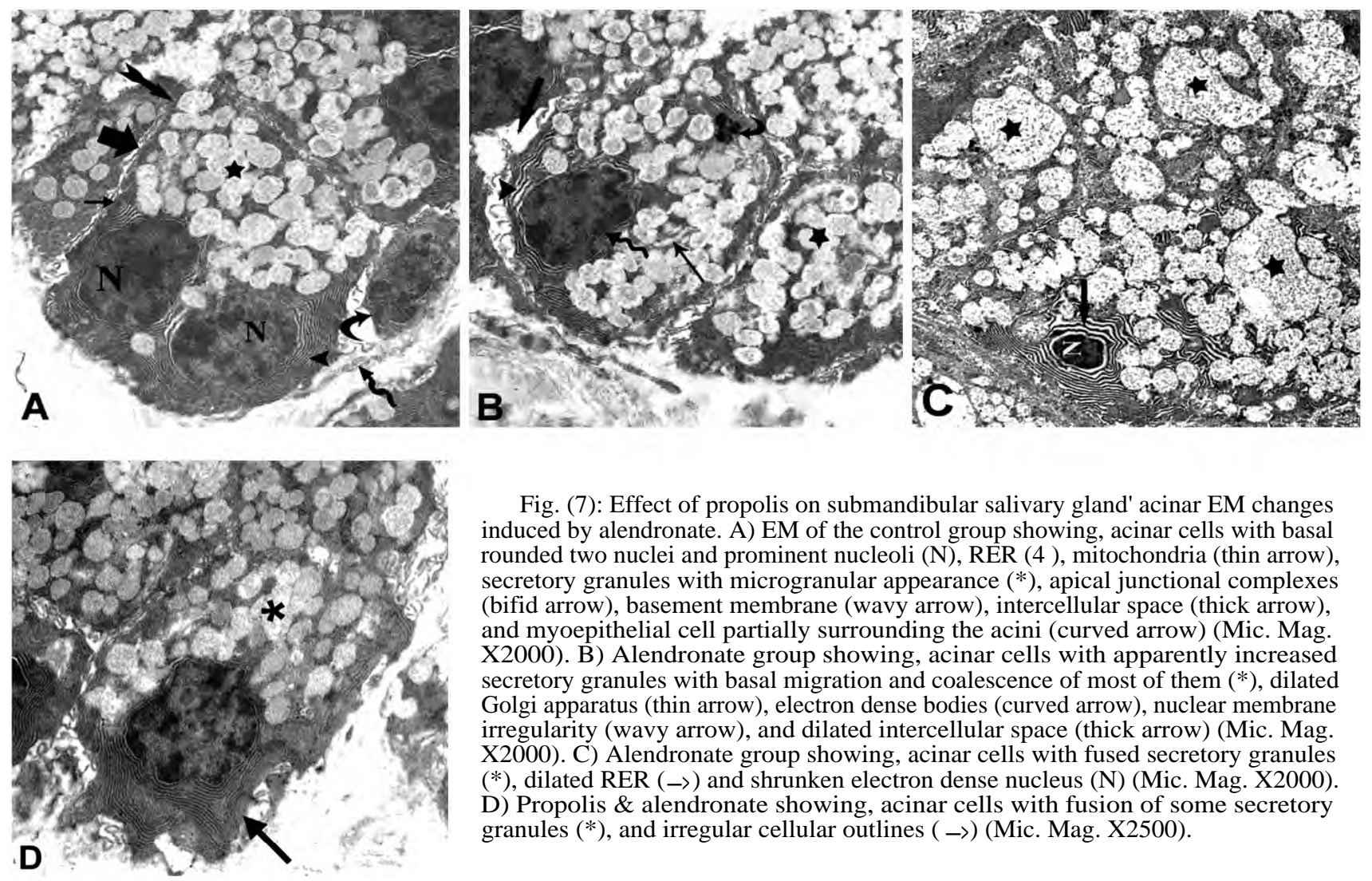

Fig. (7): Effect of propolis on submandibular salivary gland' acinar EM changes induced by alendronate. A) EM of the control group showing, acinar cells with basal rounded two nuclei and prominent nucleoli (N), RER (4), mitochondria (thin arrow), secretory granules with microgranular appearance $(*)$, apical junctional complexes (bifid arrow), basement membrane (wavy arrow), intercellular space (thick arrow), and myoepithelial cell partially surrounding the acini (curved arrow) (Mic. Mag. X2000). B) Alendronate group showing, acinar cells with apparently increased secretory granules with basal migration and coalescence of most of them $(*)$, dilated Golgi apparatus (thin arrow), electron dense bodies (curved arrow), nuclear membrane irregularity (wavy arrow), and dilated intercellular space (thick arrow) (Mic. Mag. X2000). C) Alendronate group showing, acinar cells with fused secretory granules $(*)$, dilated RER $(\rightarrow)$ and shrunken electron dense nucleus (N) (Mic. Mag. X2000). D) Propolis \& alendronate showing, acinar cells with fusion of some secretory granules $(*)$, and irregular cellular outlines ( $\rightarrow$ ) (Mic. Mag. X2500).
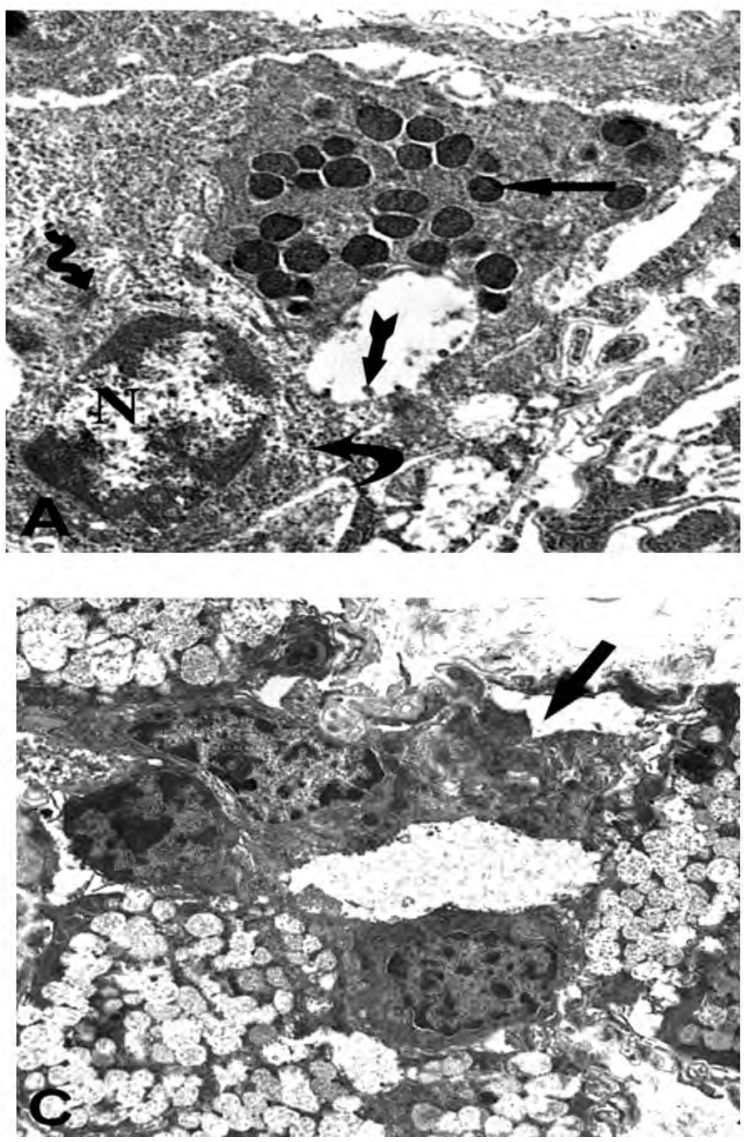

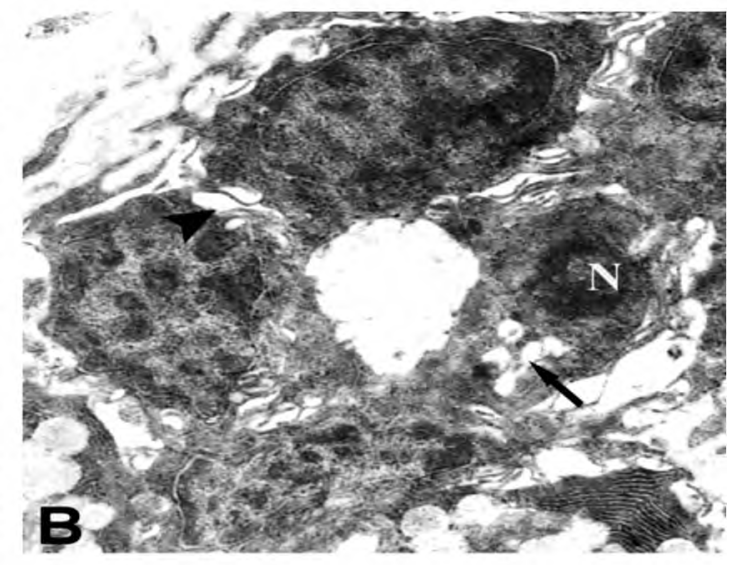

Fig. (8): Effect of propolis on submandibular salivary gland' ID EM changes induced by alendronate. A) EM of ID control group showing, two types of cells; granular cells with electron dense granules $(\rightarrow)$ and non-granular cells without granules (curved arrow), rounded centrally located nucleus $(\mathrm{N})$, junctional complexes (wavy arrow) and apical microvilli (bifid arrow) (Mic. Mag. X1500). B) Alendronate group showing, ID cells with cytoplasmic vacuolations $(\rightarrow)$, wide intercellular space (4) and shrunken electron dense nucleus (N) (Mic. Mag. X2500) C) Propolis \& alendronate group showing, some IDs with irregular destroyed cells, separated from its basement membrane $(\rightarrow)$ (Mic. Mag. X1500). 

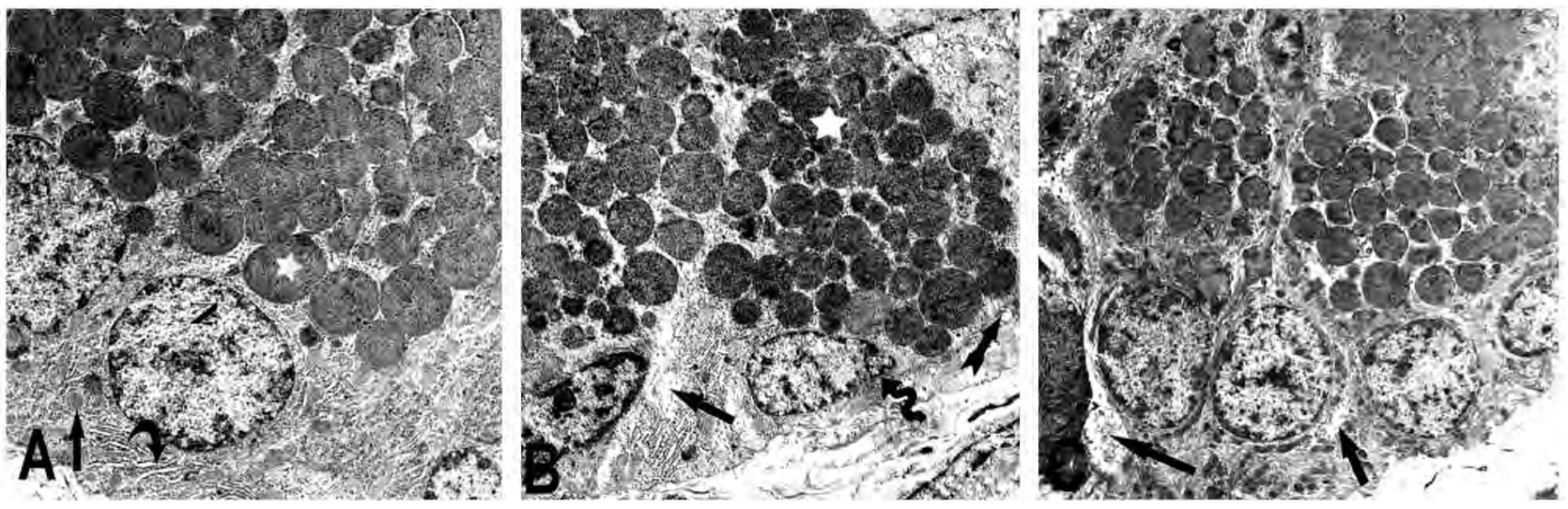

Fig. (9): Effect of propolis on submandibular salivary gland' GCT EM changes- induced by alendronate. A) Control GCT showing, cells with electron dense granules occupying their apical two thirds $(*)$, mitochondria ( $\rightarrow$ ), RER (curved arrow) and basal rounded nuclei with prominent nucleoli (N) (Mic. Mag. X2500). B) Alendronate group showing, GCT cells with apparently increased granules $(*)$, cytoplasmic rarefaction $(->)$, and vacuolation (bifid arrow), and nuclear membrane irregularity (wavy arrow) (Mic. Mag. X2000). C) Propolis \& alendronate group showing, some GCT cells with an area of cytoplasmic rarefaction ( $\rightarrow$ ) (Mic. Mag. X1500).
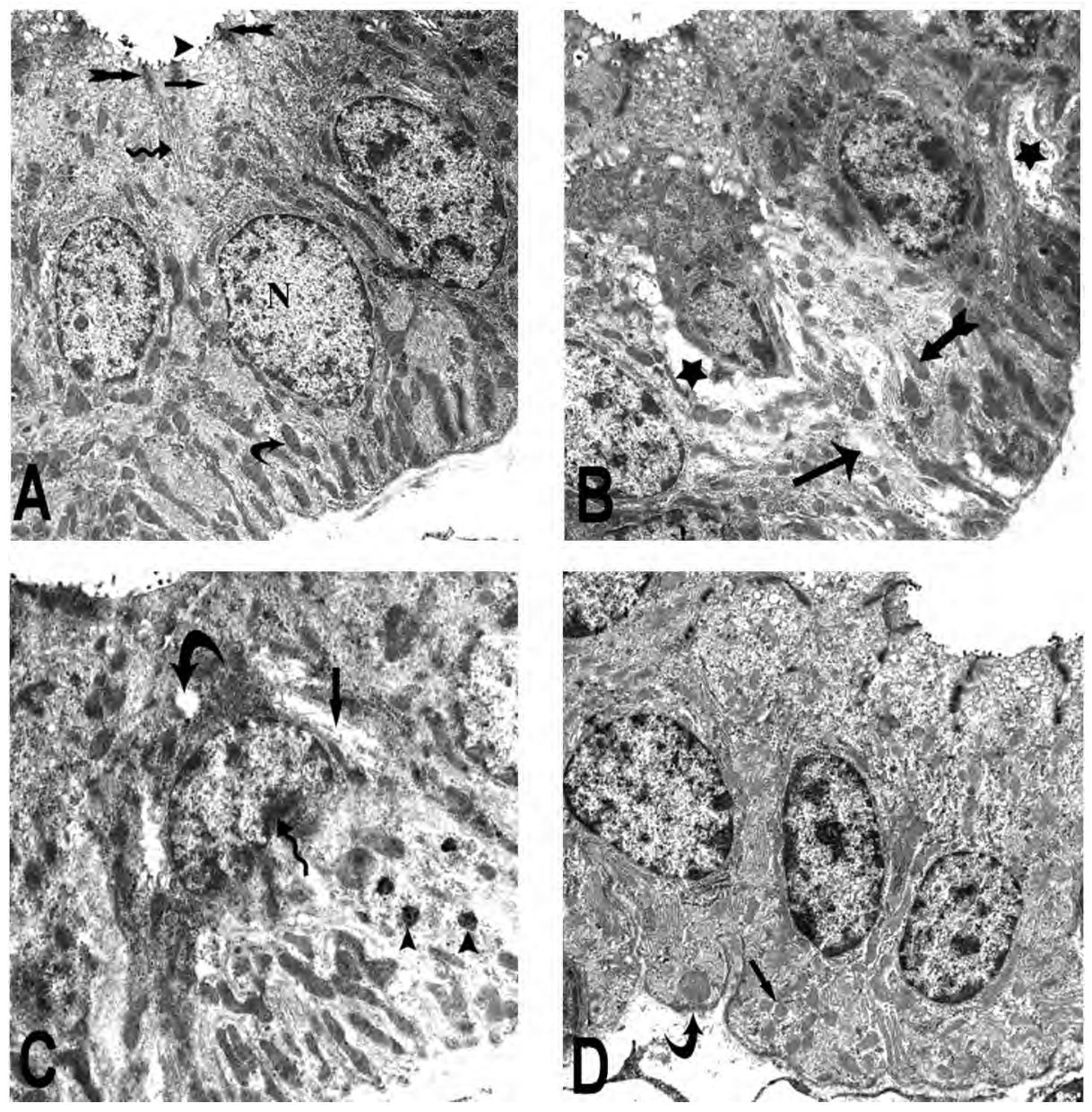

Fig. (10): Effect of propolis on submandibular salivary gland' SD EM changes-induced by alendronate. A) SDs of the control group showing, cells with apical junctional complexes (bifid arrow), and microvilli (4), apical small clear secretory vesicles $(->)$, basal rod shaped mitochondria with palisade arrangement (curved arrow) and large rounded centrally located euchromatic nuclei (N) (Mic. Mag. X2500). B) Alendronate group showing, SD cells with areas of cytoplasmic rarefaction $(*)$, and vacuolations ( $\rightarrow$ ), and mitochondrial disarrangement (bifid arrow) (Mic. Mag. X2000). C) Alendronate group showing, SD cells with electron dense bodies of variable sizes (4), mitochondria with lost cristae (curved arrow) and irregular nuclear outline (wavy arrow) (Mic. Mag. X2500). D) Propolis \& alendronate group showing, SD cells with mitochondrial disarrangement $(->)$ and detachment of cells from the basement membrane (curved arrow) (Mic. Mag. X2500). 


\section{Discussion}

Results of this work revealed disorganized glandular structure in the form of widely separated acini, irregular excretory ducts with narrow lumen and numerous cytoplasmic vacuolations, fragmented cytoplasm, either in the acini or GCTs. These changes were clarified by some authors. Through which, alendronate treatment is associated with the release of pro-inflammatory cytokines that led to multiple degenerative changes $[23,24]$. Another researcher indicated that, accumulation of the secretory material within the cells could contribute to cellular degenerative changes with subsequent cell death, duct shrinkage and irregularity [25]

Additionally, alendronate has an effect on histamine-forming enzymes leads to increased histamine synthesis as well as its release [26,27]. The latter results in increased capillary permeability, and the hydrostatic pressure and consequentially leading to tissue edema [28]. So, this could be the cause of wide space in between and around the acini as well as the ducts.

Regarding the occurrence of cytoplasmic vacuolations of acinar and duct cells; many authors documented that alendronate reduce the mitochondrial membrane potential leading to generation of Reactive Oxygen Species (ROS) and free radicals resulting in lipid peroxidation and damage of cell membranes as well as membranes of the cell organelles ending in failure of the energy-dependent $\mathrm{Na}+\mathrm{K}^{+}$ion pumps in the cell [29-31]

As well, these changes lead to accumulation of $\mathrm{Na}+$ inside the cells with entry of water expressing cellular swelling and vacuolations. Therefore, this could explain the dilated RER, and Golgi apparatus as well as cytoplasmic rarefaction that detected by EM examination. Additionally, the attributed accumulation of the unprenylated proteins in the organelle cisternae due to interference with their transport and modification in Golgi apparatus could also explain its dilatation [32].

In the present research, the statistical results of the combined PAS-AB revealed, significant increase in the mean color intensity of PAS-AB stains in the alendronate group as compared with the control group. These all might be due to exocytosis interruption by alendronate, consequently, the amount of secretory granules is increased [18]

As regards the immunohistochemical results of the present work. It showed significant decrease in the mean color intensity of a-SMA immunostaining of the myoepithelial cells of alendronate group when compared to the control group. This confirmed the interruptive effect of alendronate on the secretory process of the gland, which was due to disruption of the actin cytoskeleton by alendronate [33]. Alendronate could inhibit Farnesyl Pyrophosphate Synthase (FPPS) enzyme involved in the mevalonate pathway which is essential for the production of Geranylgeranyl Pyrophosphate (GGPP) and Farnesyl Pyrophosphate (FPP) [34] These metabolites are necessary for the prenylation of small GTPases; Rab and Rho, which act as regulators of intracellular vesicular trafficking and secretory function of the salivary glands [18]. Additionally, mevalonate pathway is associated with reduction of coenzyme Q 10 which causes mitochondrial dysfunction with ATP depletion so; the cells had no energy for the secretory process to take place. These previous mechanisms could explain the most prominent finding detected by EM which was in the form of increased secretory granules with their basal migration, and coalescence of most of them in the serous acini as well as GCT cells $[35,36]$.

Moreover, the abnormal shaped mitochondria with lost cristae and dilated intercellular space were observed as an EM results in the present work. These findings may be attributed to the release of ROS, causing disturbance of the plasma membrane integrity, and consequently beside edema, could disrupt the intercellular junctions [29,37]

Too, electron dense bodies of variable sizes and heterogeneous consistency in the cytoplasm of acinar and duct cells were recorded. These most probably are secondary lysosome. As the release of ROS besides occurrence of lipid peroxidation requires activation of lysosomal hydrolytic enzymes [37-39].

Furthermore, shrunken nuclei with dense chromatin were noticed as an EM result of the acinar and duct cells. Since Alendronate induced mitochondrial dysfunctions, this could induce causing in the mitochondrial membrane permeability with the release of cytochrome $\mathrm{c}$ as well as other proapoptotic factors like caspase- 9 and -3 causing apoptotic cell deaths. Subsequently, DNA fragmentation and chromatin condensation ensues $[35,40,41]$

In the present research, propolis administration displayed moderate improvement of the previous pathological findings of the submandibular salivary gland induced by alendronate. It was documented that propolis has protective effect against dry mouth induced by parotid salivary gland dysfunctions due to exposure to radiation [42]. This could attribute 
to the protection of cell membranes with subsequent preservation of the intracellular signal transduction involved in salivary secretion.

Moreover, propolis is able to scavenge freeradicals and its antioxidant properties are due to its polyphenol composition [34,44]. So, propolis could inhibit the activation of the apoptotic pathways in normal cells exposed to oxidants [45].

It was reported that propolis could inhibit the production of pro-inflammatory cytokines such as Interleukin IL-1 3 , Tumor Necrosis Factor (TNF)a, and Monocyte Chemoattractant Protein (MCP)1. It also reduces the pro-inflammatory cyclooxygenase (COX2) and lipoxygenase enzyme, important for leukotriene production. This potent antiinflammatory action could inhibit the release of histamine so decreasing vascular permeability as well as edema [46,47].

Recently, the anti-inflammatory action of propolis is through the reduction of the nuclear factor kappa-light-chain-enhancer of activated B cells (NF-KB) stimulation as well as suppression of the synthesis of ubiquitin units; preventing its action on the cell proteins [48].

\section{Conclusion:}

Based on the current study, it can be concluded that, propolis improve alendronate-induced damaging effects on the rat submandibular salivary gland through its antioxidant and anti-inflammatory actions. In this light, propolis is recommended to for people who take alendronate for a long period to minimize its harmful effects.

\section{References}

1- SHEHU A., ROHIN M.A.K., ABD AZIZ A. and ISMAIL S.: "Antifungal, characteristic properties and composition of bee glue (propolis)." Journal of Chemical and Pharmaceutical Research, 7 (3): 1992-6, 2015.

2- BANKOVA V., POPOVA M. and TRUSHEVA B.: "New emerging fields of application of propolis." Macedonian Journal of Chemistry and Chemical Engineering, 35 (1): 1-11, 2016.

3- CHAN G.C., CHEUNG K. and SZE D.M.: "The immunomodulatory and anticancer properties of propolis." Clinical Reviews in Allergy \& Immunology Journal, 44: 262-73, 2013.

4- SFORCIN J.M. and BANKOVAB V.: "Propolis: Is there a potential for the development of new drugs?" Ethnopharmacology Journal, 133: 253-60, 2011.

5- ARAUJO M.A.R., LIBÉRIO S.A., GUERRA R.N.M., RIBEIRO M.N.S. and NASCIMENTO F.R.F.: "Mechanisms of action underlying the anti-inflammatory and immunomodulatory effects of propolis: A brief review."
Revista Brasileira de Farmacognosia, 22 (1): 208-19, 2012.

6- FAROOQUI T. and FAROOQUI A.A.: "Beneficial effects of propolis on human health and neurological diseases". Frontiers in Bioscience Journal, 4: 779-93, 2012.

7- Sforcin J.M.: "Biological properties and therapeutic applications of propolis." Phytotherapy Research Journal, 30: 894-905, 2016.

8- PAPAPOULOS S.E.: "Bisphosphonates: How do they work?" Best Practice \& Research Journal: Clinical Endocrinology \& Metabolism, 22 (5): 831-47, 2008.

9- OTTO S.: "Medication-Related Osteonecrosis of the Jaws: Pharmacological Aspects of Antiresorptive Drugs: Bisphosphonates and Denosumab." Springer. Verlag. Berlin. Heidelberg, P.: 1-15, 2015.

10- CERMAK K., SHUMELINSKY F., ALEXIOU J. and GEBHART M.J.: "Subtrochanteric femoral stress fractures after prolonged alendronate therapy". Clinical Orthopaedics and Related Research Journal, 468: 1991-6, 2010.

11-DRAKE M.T., CLARKE P.L. and KHOSLA S.: "Bisphosphonates: Mechanism of action and role in clinical practice." Mayo Clinic Proceedings Journal, 83 (9): 1032-45, 2008.

12- PAPAPETROU P.D.: "Bisphosphonate-associated adverse events". Hormones Journal, 8 (2): 96-110, 2009.

13- MARTINI F.H., OBER W.C., GARRISON C.W., WELCH K., HUTCHINGS R.T. and IRELAND K.: "Anatomy and Physiology". ${ }^{2 n d}$ edition. Pearson Education South Asia Pte. Ltd. Philippine. P: 653-93, 2007.

14- SATALOFF R.T., GULLANE P.J. and GOLDSTEIN D.P.: "Sataloff's Comprehensive Textbook of Otolaryngology: Head and Neck Surgery: Head and Neck Surgery." Volume 5. Jaypee Brothers Medical Publishers. New Delhi. Panama. London. USA. P.: 383-408, 2016.

15- LAMSTER I.B. and NORTHRIDGE M.E.: "Improving Oral Health for The Elderly: An Interdisciplinary Approach." Springer Science \& Business Media. New York, P.: 327-52, 2008.

16- KILICOGLU S.S., KILICOGLU B. and ERDEMLI E.: "Ultrastructural view of colon anastomosis under propolis effect by transmission electron microscopy." World Journal of Gastroenterology, 14: 4763-70, 2008.

17- MOUSA A.M.: "Histological and immunohistochemical study of the effect of monosodium l-glutamate on the jejunal mucosa of adult albino rat and the possible role of propolis." The Egyptian Journal of Histology, 36: 72534, 2013.

18-OLIVEIRA_T.C., BRADASCHIA-CORREA V., CASTRO J.R., SIMOES A. and ARANA-CHAVEZ V.E.: "Ultrastructural and biochemical analysis of the effects of alendronate on salivary glands of young rats." Archives of Oral Biology Journal, 59: 1307-11, 2014.

19- SUVARNA S.K., LAYTON C. and BANCROFT J.D.: "Bancroft's Theory and Practice of Histological Techniques." 7th edition. Elsevier. Churchill Livingstone. P: 105-23 \& P.: 215-38, 2013.

20- ROSE L.F., WU J.C., CARLSSON A.H., TUCKER D.I., LEUNG K.P. and CHAN R.K.: "Recipient wound bed characteristics affect scarring and skin graft contraction." 
The International Journal of Tissue Repair and Regeneration, 23 (2): 287-96, 2015.

21- GAUTIER J.C.: "Drug Safety Evaluation: Methods and Protocols." Methods in Molecular Biology. 2nd edition. Springer. New York, P.: 83-96, 2017.

22- CHEVILLE N.F. and STASKO J.: "Techniques in electron microscopy of animal tissue." Veterinary Pathology Journal, 51 (1): 28-41, 2014.

23- ALJAYER A., EL-BAZ D. and BASHIR M.: "Impacts of omega- 3 fatty acids on the age related changes in the submandibular salivary glands of albino old rats." Nature and Science Journal, 13 (6): 22-8, 2015.

24- MORITA M., IWASAKI R., SATO Y., KOBAYASHI T., WATANABE R., OIKE T., et al.: "Elevation of proinflammatory cytokine levels following anti-resorptive drug treatment is required for osteonecrosis development in infectious osteomyelitis." Scientific Reports Journals, 7: 46322-33, 2017

25- EL-MAGHRABY E.M.F.: "Effect of whey protein and nandrolone in rat submandibular salivary glands." Nature and Science Journal, 10 (9): 10-19, 2012.

26- DENG X., YU Z., FUNAYAMA H., SHOJI N., SASANO T., IWAKURA Y., et al.: "Mutual augmentation of the induction of the histamine-forming enzyme, histidine decarboxylase, between alendronate and immunostimulants (IL-1, TNF, and LPS), and its prevention by clodronate." Toxicology and Applied Pharmacology Journal, 213 (1): 64-73, 2006.

27- EL-AGAMY A.A., AFIFI O.K. and SHETA A.A.: "Protective role of panax gensing on fluvoxamine maleate induced structural changes in the submandibular salivary gland of rats." Nature and Science Journal, 12 (4): 21-9, 2014.

28- SKIRVEN T.M., OSTERMAN A.L., FEDORCZYK J. and AMADIO P.C.: "Rehabilitation of the Hand and Upper Extremity." 6th edition. Elsevier. Philadilphia, P.: 84557, 2011.

29- CARVALHO N.S., SILVA M.M., SILVA R.O., NICOLAU L.A.D., ARAÚJO T.S.L., COSTA D.S., et al.: "Protective effects of simvastatin against alendronate-induced gastric mucosal injury in rats." Journal of Digestive Diseases and Sciences, 61: 400-9, 2016.

30- HAMZA S.A., ALY H.M., SOLIMAN S.O. and ABDALLAH D.M.: "Ultrastructural study of the effect of zinc oxide nanoparticles on rat parotid salivary glands and the protective role of quercetin." Alexandria Dental Journal, 41: 232-7, 2016.

31- MAHMOUD E.F. and MAHMOUD M.F.: "Effect of pomegranate peel extract on submandibular salivary glands of streptozotocininduced diabetes in rats: Histological, immunohistochemical and ultrastructural study." Journal of Advances in Biology \& Biotechnology, 13 (3): $1-15,2017$.

32- ZAFAR S., COATES D.E., CULLINAN M.P., DRUMMOND B.K., MILNE T. and SEYMOUR G.J.: "Zoledronic acid and geranylgeraniol regulate cellular behaviour and angiogenic gene expression in human gingival fibroblasts." Journal of Oral Pathology and Medicine, 43: 711$21,2014$.
33- KAZMERS N.H., MA S.A., YOSHIDA T. and STERN P.H.: "Rho GTPase signaling and PTH 3-34, but not PTH $1-34$, maintain the actin cytoskeleton and antagonize bisphosphonate effects in mouse osteoblastic MC3T3-E1 cells." Bone Journal, 45: 52-60, 2009.

34- TRICARICO P.M., EPATE A., CROVELLA S. and CELSI F.: "Alendronate treatment induces IL-1B expression and apoptosis in glioblastoma cell line." Inflammopharmacology Journal, 1-6, 2017.

35- TRICARICO P.M., CROVELLA S. and CELSI F.: "Mevalonate pathway blockade, mitochondrial dysfunction and autophagy: A possible link." International Journal of Molecular Sciences, 16: 16067-84, 2015.

36- HALAWA A.M., MOHAMED D.G. and OBEID R.F.M.A.: "Capsaicin induced histological and ultrastructural changes in the submandibular salivary gland of albino rats." Future Dental Journal, 2: 22-7, 2016.

37- El-GHAZZAWY I.F., MELEIS A.E., FARGHALY E.F. and SOLAIMAN A.: "Histological study of the possible protective effect of pomegranate juice on bisphenol-A induced changes of the caput epididymal epithelium and sperms of adult albino rats." Alexandria Journal of Medicine, 47: 125-37, 2011.

38- NAGANO Y., MATSUI H., SHIMOKAWA O., HIRAYAMA A., NAKAMURA Y., TAMURA M., et al.: "Bisphosphonate-induced gastrointestinal mucosal injury is mediated by mitochondrial superoxide production and lipid peroxidation." Journal of Clinical Biochemistry and Nutrition, 51 (3): 196-203, 2012.

39- GHADIALLY F.N.: "Ultrastructural Pathology of the Cell and Matrix: A Text and Atlas of Physiological and Pathological Alterations in the Fine Structure of Cellular and Extracellular Components." ${ }^{\mathrm{rd}}$ edition. ButterworthHeinemann. London. Boston. Singapore. Sydney. Toronto. Wellington. P.: 589-766, 2013.

40- MÖNKKÖNEN H., AURIOLA S., LEHENKARI P., KELLINSALMI M., HASSINEN I.E., VEPSÄLÄINEN J., et al.: "A new endogenous ATP analog (ApppI) inhibits the mitochondrial adenine nucleotide translocase (ANT) and is responsible for the apoptosis induced by nitrogencontaining bisphosphonates." British Journal of Pharmacology, 47: 437-45, 2006.

41- KUMAR V., ABBAS A.K. and ASTER J.C.: "Robbins Basic Pathology E-Book." 10th edition. Elseveir. Philadilphia, P.: 31-56, 2018.

42- MOTALLEBNEJAD M., ABEDI S.M., SEYEDMAJIDI M., MOGHADAMNIA A.A., ASHRAFPOUR M., SALEHI M., et al.: "Evaluation of protective effect of propolis on parotid salivary glands in gamma-irradiated rats." The Journal of Contemporary Dental Practice, 15 (1): 8-11, 2014.

43- DALEPRANE J.B. and ABDALLA D. S.: "Emerging roles of propolis: Antioxidant, cardioprotective, and antiangiogenic actions." Evidence-Based Complementary and Alternative Medicine Journal, 2013: 175135-43, 2013.

44- ZAGMUTT S., LEIVA E., MUJICA V. and WEHINGER S.: "Protective effect of propolis extract on pancreatic $\beta$ cell under oxidative stress in vitro." Journal of Food and Nutrition Research, 4 (6): 400-7, 2016. 
45- BAKCHICHE B., HABATI M., BENMEBAREK A. and GHERIB A.: "Total Phenolic, flavonoid contents and antioxidant activities of honey and propolis collected from region of Laghouat (South of Algeri)". World News of Natural Sciences Journal, 11: 91-7, 2017.

46- TOLBA M.F., AZAB S.S., KHALIFA A.E., ABDELRAHMAN S.Z. and ABDEL-NAIM A.B.: "Caffeic acid phenethyl ester, a promising component of propolis with a plethora of biological activities: A review on its antiinflammatory, neuroprotective, hepatoprotective, and cardioprotective effects". International Union of Biochemistry and Molecular Biology, 65 (8): 699-709, 2013.

47- SABIR A.: "The effect of propolis on cytokines during dental pulp inflammation". Journal of Apiculture, 31 (1): 135-42, 2016

48- AMINIMOGHADAMFAROUJ N. and NEMATOLLAHI A.: "Propolis diterpenes as a remarkable bio-source for drug discovery development: A Review". International Journal of Molecular Sciences, 18: 1290-304, 2017.

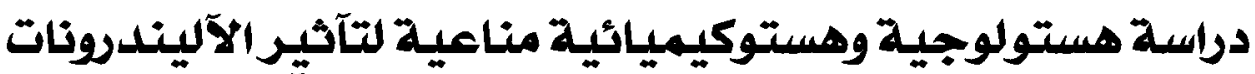

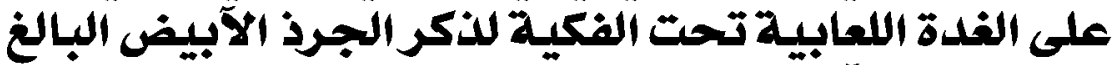

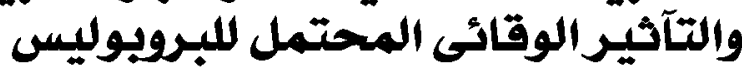

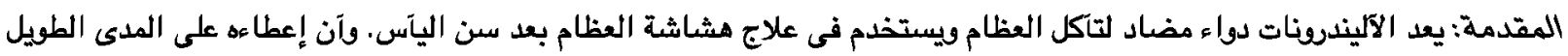

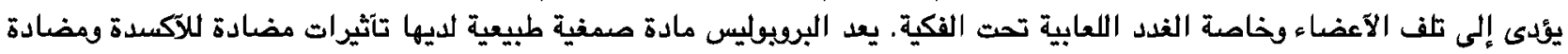
اللإلتهابات.

الهدف: آجرى هذا العمل لدراسة تآثير الآليندرونات على التركيب الهستولوجى للغدة اللعابية تحت الفكية فى ذكر الجرن الآيض البالغ والتآثير الوقائى المحتمل اللبربوليس.

المواد وطرق البحث: تم تقسيم •ع من ذكود الجرذان البيضاء البالغة إلى آربع مجموعات (ـ ـ جرذان لكل منهم)، الججموعة الضسابطة،

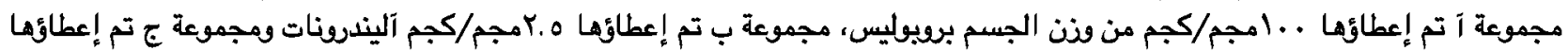

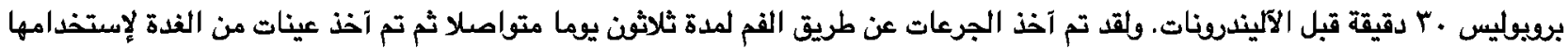
فى الدراسات الهستولوجية والهستوكيميائية الهناعية بإستخدام الهيكروسكوبي الضونئي فالإلكتروني.

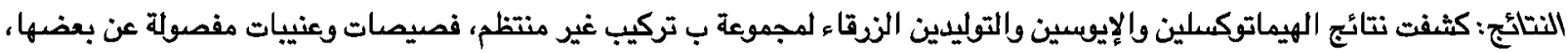

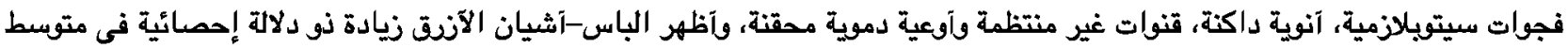

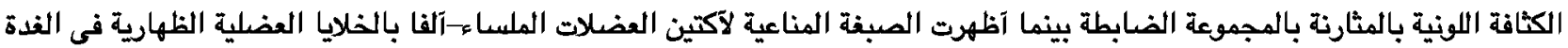

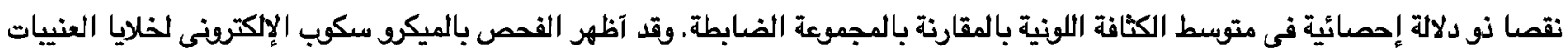

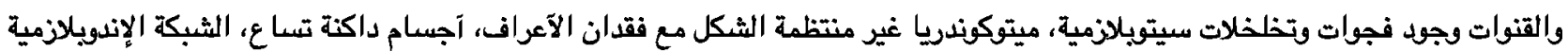

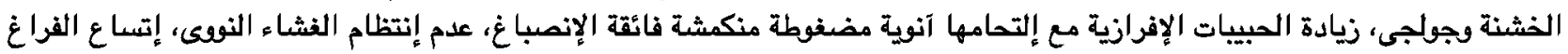
حل النواة والمسافات بين الخلايا ، وقد آظهرت مجموعة جاته تحسن متوسط اللنتائج المرضية السابقة. الإستتاج: الآليندرونات قد آحدث تآثيرات ضارة على التركيب الهستولوجى للغدة اللعابية تحت الفكية للجرذان وآن إعطاءه مع البرويوليس

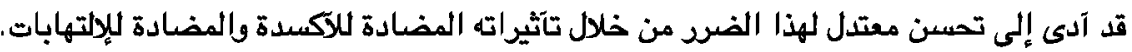

